\title{
A new species of Delphinium L. (Ranunculaceae) from Dagestan (Eastern Caucasus)
}

\author{
R. A. Murtazaliev ${ }^{1,2 *}$, A. N. Luferov ${ }^{3}$ \\ ${ }^{1}$ Caspian Institute of Biological resources of Dagestan Federal Research Center of RAS, \\ M. Gadjieva Str., 45, Makhachkala, 367000, Russian Federation \\ ${ }^{2}$ State Natural Reserve “Dagestanskiy”, Gagarina Str., 120, Makhachkala, 367010, Russian Federation \\ E-mail: murtazaliev.ra@yandex.ru; ORCID iD: http://orcid.org/0000-0002-2895-213X \\ ${ }^{3}$ I. M. Sechenov First Moscow State Medical University, Pharmaceutical Natural Science Department, \\ Izmailovskiy Boulevard, 8, Moscow, 105043, Russian Federation \\ E-mail:luferovc@mail.ru; ORCID iD: http://orcid.org/0000-0003-2397-7378 \\ * Corresponding author
}

Keywords: Delphinium samurense, diagnostic features, distribution, ecological and cenotic characteristics.

Summary. The new species Delphinium samurense Murtazaliev et Luferov (sect. Diedropetala Huth) is described from the Eastern Caucasus. The novelty is endemic to southern Dagestan (Rutul district). Its morphological differences from the closely related species D. macropogon Prokh. are shown. Distribution and ecology of the new species are characterized.

\section{Новый вид рода Delphinium L. (Ranunculaceae) из Дагестана (Восточный Кавказ)}

\author{
Р. А. Муртазалиев ${ }^{1,2}$, А. Н. Луферов ${ }^{3}$ \\ ${ }^{I}$ Прикаспийский институт биологических ресурсов Дагестанского Федерального исследовательского иентра РАН; \\ ул. М. Гаджсиева, 45, г. Махачкала, 367000, Россия \\ ${ }^{2}$ Государственный природный заповедник «Дагестанский», ул. Гагарина, 120, г. Махачкала, 367010, Россия \\ ${ }^{3}$ Первый Московский государственный медииинский университет им. И. М. Сеченова, кафедра \\ фармацевтического естествознания, Измайловский бульвар, 8, г. Москва, 105043, Россия
}

Ключевые слова: диагностические признаки, распространение, эколого-ценотическая характеристика, Delphinium samurense.

Аннотация. С территории Восточного Кавказа описан новый вид Delphinium samurense Murtazaliev et Luferov (sect. Diedropetala Huth) - эндемик южного Дагестана (Рутульский район). Показаны его морфологические отличия от близкого вида D. macropogon Prokh. Приведены сведения о распространении и эколого-ценотических особенностях нового вида. 
Floristic studies of the southern part of the Republic of Dagestan resulted in finding the specimens of Delphinium L. (Ranunculaceae), which have not been previously recorded for the Caucasus. When studying them, attention was paid to the morphological features of the rhizome: the presence of a tuberous nodosity; structural features of the stems, leaves, pedicels, sepals, nectaries, staminodes, stamens and carpels, fruits, and other structural features that are traditional diagnostic characters for the species of the genus Delphinium (Huth, 1895; Nevsky, 1937; Grossheim, 1950; Pawłowski, 1963; Kemularia-Natadze, 1966; Munz, 1967; Dimitrova, 1969; Malyutin, 1973, 1987, 2001; Tzvelev, 1996, 2001; Wang, Warnock, 2001; Luferov, 2012, 2018). The study of the collected plants showed that they belong to a new species, the description of which is given below.

Delphinium samurense Murtazaliev et Luferov, sp. nov. (sect. Diedropetala Huth).

Perennials, 70-120 $\mathrm{cm}$ high, with a tuberous nodose rhizome $2.5-4 \times 1.5-2.5 \mathrm{~cm}$ and numerous branching thin adventitious roots (Fig. 1). Stems simple or slightly branched in the upper part, rounded and ribbed, with simple white very short (0.1-0.3 mm long) straight or arcuate, appressed or slightly deflected hairs; in the upper half of the shoot and especially in the inflorescence, with an admixture of yellowish (reddish) or white glandular trichomes $0.2-0.5 \mathrm{~mm}$ long, straight, protruding or subappressed, ovoid and broadened at the base and containing light yellow or colorless essential oil. Basal and lower stem leaves long-petiolate (petioles 10-22 cm long, 3-4 times exceeding leaf blade, flattened, grooved on the adaxial side, semiamplexicaul at the base, pubescent as stems). Blades of the basal leaves rounded-reniform or rounded-cordate, palmately dissected into 3-5(7) rhomboid segments on thin petiolules 3-8 $\mathrm{mm}$ long. Leaf segments of the first order dissected into up to 3-4 orders into numerous oblong-lanceolate or linear, entire or with single oblong-lanceolate teeth with acute or pointed tips, segments and lobes, glabrous above, with simple sparse scattered appressed hairs below, usually densely hairy at the margins; at the base of the leaf blades with a wide notch, stub or wedge-shaped. Upper leaves ovate-rhomboid, dissected into 3-5 segments, which, in turn, are dissected into narrowlanceolate and linear lobes of 2-3 orders. All leaves with strongly protruding veins on the lower surface, and more or less revolute margins of blades. Apical raceme multi-flowered (20-55 flowers), nar- row, compact (Fig. 2). Bracts entire, narrowly lanceolate, $8-15 \times 0.8-3 \mathrm{~mm}, 1.5-2$ times longer than the pedicels or equal to them. At the base of the inflorescence, the bracts twice or thrice trifid, 4-7 $\times$ 3-6 cm, 2-3 times longer than the pedicels. Two bracteoles attached close to each other, located 1-3 $\mathrm{mm}$ from the calyx, linear-subulate, entire, usually arcuate, 3-6 $\times 0.5-1.5(2) \mathrm{mm}$. Calyx white, often with yellowish and light green stripes on the bottom, after drying often (not always) turning blue, covered from the outside with simple, very short (0.2-0.4 mm long), appressed, arcuate and straight hairs. Spur straight or slightly arcuate, $14-17 \mathrm{~mm}$ long, 2-2.5(3) mm thick. (fig. 3a), 2-3 times longer than the pedicels. Lateral sepals 10-14 $\times 4-7$ $\mathrm{mm}$, broadly cuneate at the base, acute or rounded at the tip (fig. 3b). Lower sepals 10-14 × 2-4 mm, narrowly cuneate at the base, pointed at the top (fig. 3c). Corolla blue, with blue, less often purple, longitudinally arranged veins. Petal nectaries $10-13 \times 1.5-2 \mathrm{~mm}$, narrow, pointed at the base and broadened to the bifid top with narrow acute lobes

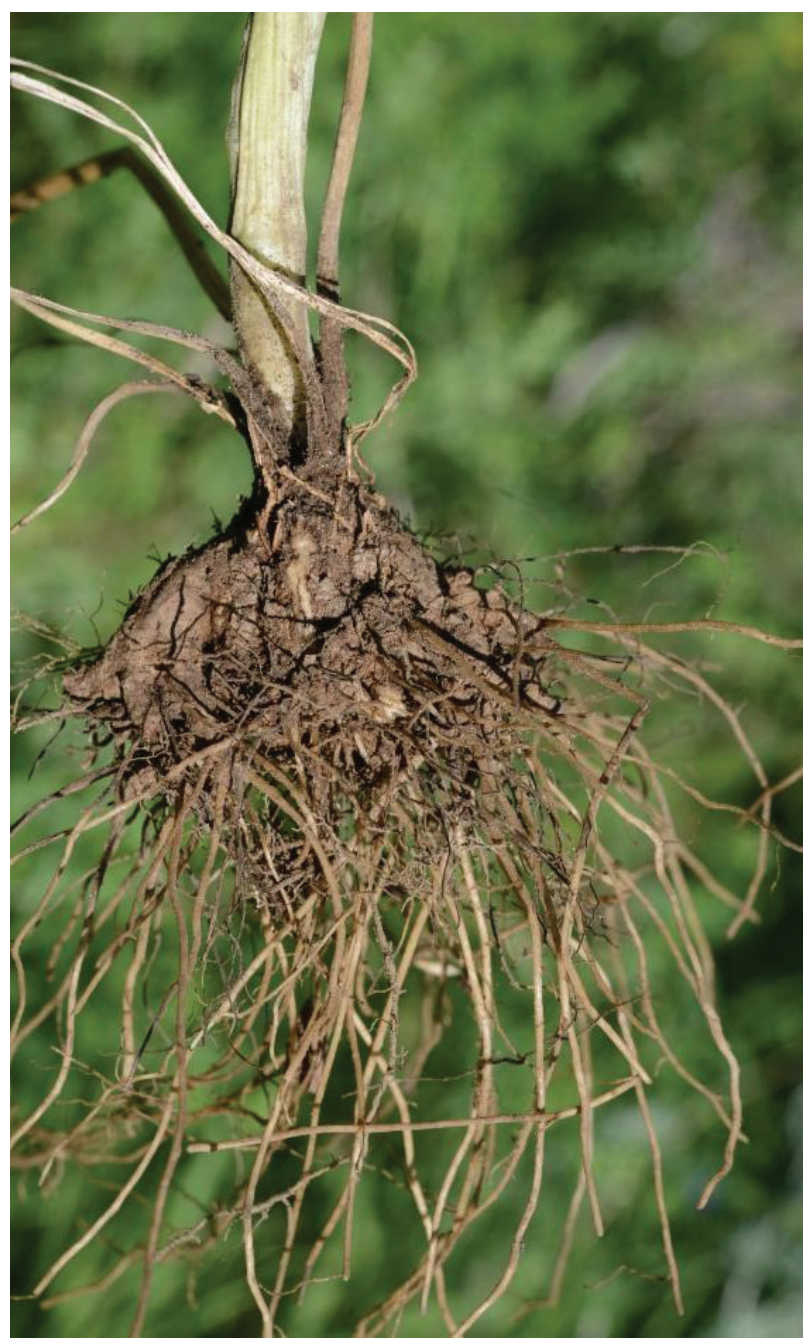

Fig. 1. The underground part of Delphinium samurense. 
(fig. 3e). The lower petals (staminodia) $4-8 \mathrm{~mm}$ long, with blades bifid for $25-40 \%$ of their length, on the inner (upper) side with a thick yellow or yellow-orange pubescence of simple, 1-2 mm long, hairs (fig. 3d). Filaments thin, glabrous. Anthers broadly elliptic (fig. 3f). Three carpels (fig. 4) and follicles $15-19 \times 2.5-3 \mathrm{~mm}$, with a slightly protruding dorsal vein, smooth on the sides, with appressed or subappressed short, $0.3-1 \mathrm{~mm}$ long, thin white hairs. Stylodia slightly arched, $4-6 \times 0.3-0.6 \mathrm{~mm}$. Seeds obovate or ellipsoidal, $0.7-1 \times 0.6-0.8 \mathrm{~mm}$, black; their surface is covered with small pressed scales.

Holotype: "Dagestan, Rutulsky district, above the village of Djinykh, $1790 \mathrm{~m} .41^{\circ} 67^{\prime} 49.1^{\prime \prime} \mathrm{N}$, 4704'02.2"E. 26 VII 2016. R. Murtazaliev" (LE, fig. 5; iso - LE, DAG, MHA). Голотип: «Дагестан, Рутульский р-н, выше с.[ела] Джиных, 1790 м.

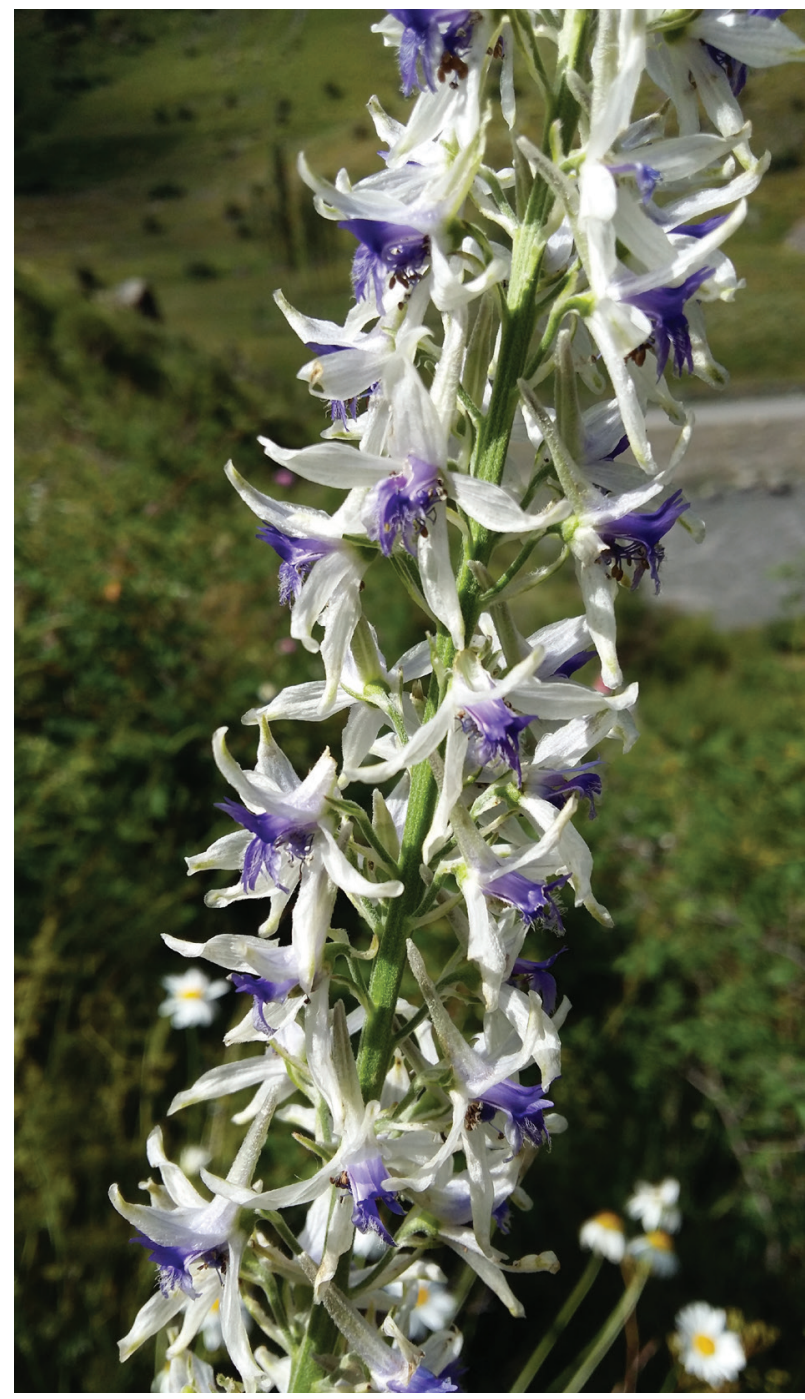

Fig. 2. The inflorescence of Delphinium samurense.

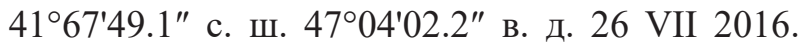
P. Муртазалиев» (LE, рис. 5; изо - LE, DAG, MHA).

Paratypes: "Dagestan, Rutulsky district, in the vicinity of the village of Tsakhur, along the road, $41^{\circ} 65^{\prime} 18.3^{\prime \prime} \mathrm{N}, 47^{\circ} 12^{\prime} 67.2^{\prime \prime E} .27$ VII 2016, R. Murtazaliev" (DAG); "Dagestan ASSR, Rutulsky district, the left bank of Samur River, between villages Tsakhur and Helmetz, $1700 \mathrm{~m}, 41^{\circ} 64^{\prime} 59.3^{\prime \prime} \mathrm{N}$, $47^{\circ} 15^{\prime} 85.3^{\prime \prime}$ E. 22 VII 1978. Yu. Menitsky, T. Popova. № 495” (LE); "Dag. ASSR, Rutulsky district, port side of the Samur River, vicinity of Helmetz, $\sim 1700 \mathrm{~m}$, shale scree, $41^{\circ} 62^{\prime} 98.5^{\prime \prime} \mathrm{N}, 47^{\circ} 18^{\prime} 15.8^{\prime \prime} \mathrm{E}$. 22 VII 1978. T. Popova, Yu. Menitsky. № 632" (LE). Паратипы: «Дагестан, Рутульский р-н, в

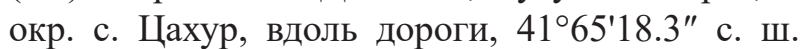
47¹2'67.2" в. д. 27 VII 2016, Р. Муртазалиев» (DAG); «Даг. АCCP, Рутульский p-н, левый борт p. Самур, между сел. Цахур и Гельмец, $~ 1700$

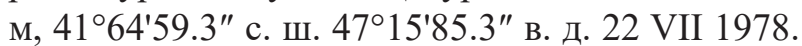
Ю. Меницкий, Т. Попова. № 495» (LE); «Даг. АССР, Рутульский р-н, левый борт р. Самур, окр. сел. Гельмец, $\sim 1700$ м, сланцевая осыпь, $41^{\circ} 62^{\prime} 98.5^{\prime \prime}$ с. ш. $47^{\circ} 18^{\prime} 15.8^{\prime \prime}$ в. д. 22 VII 1978. Т. Попова, Ю. Меницкий. № 632» (LE).

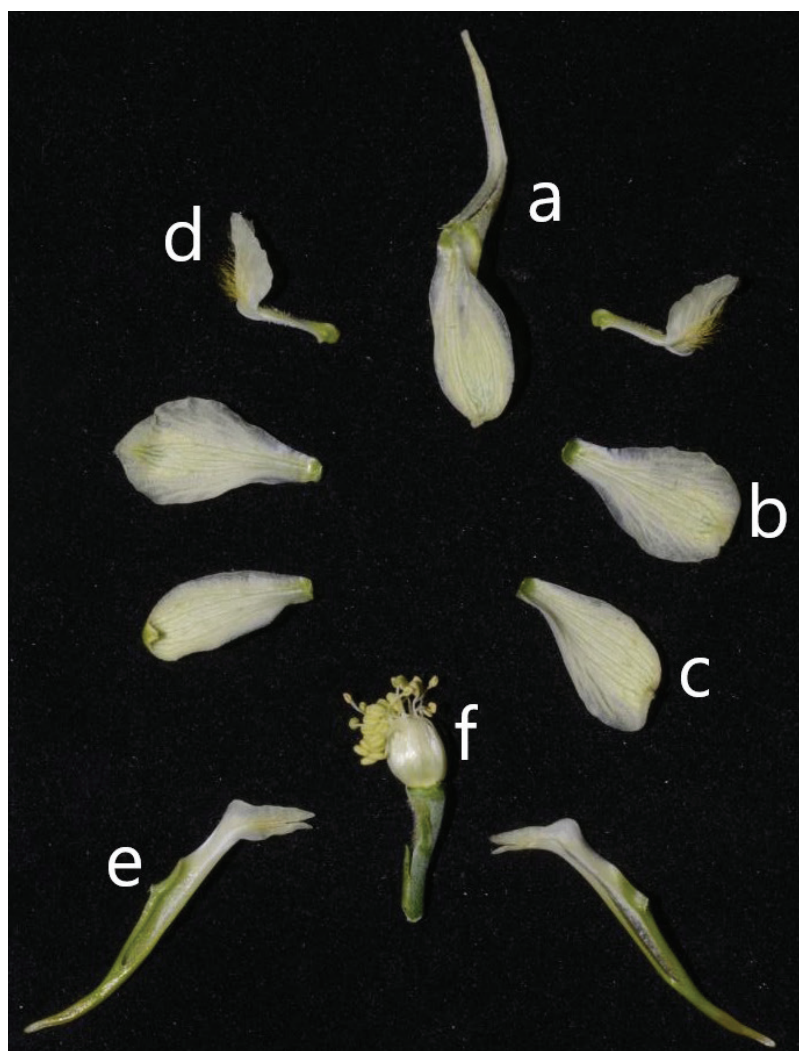

Fig. 3. Flower parts of Delphinium samurense: a -upper sepal with spur; b - lateral sepals; c - lower sepals; d staminodia; $\mathrm{e}$ - nectaries; $\mathrm{f}$ - androecium with the upper part of the pedicel. 
Affinities. The species is closest to D. macropogon Prokh. (fig. 6), from which it differs well by a longer inflorescence, the colour and length of sepals, the length of the spur, the colour of nectar- ies and staminodes, the colour and length of hairs on staminodes, the length of follicles and stylodia (Table).

Morphological features of Delphinium samurense and D. macropogon

\begin{tabular}{|l|l|l|}
\hline \multicolumn{1}{|c|}{ Features } & \multicolumn{1}{c|}{ D. samurense } & \multicolumn{1}{c|}{ D. macropogon } \\
\hline Inflorescence & $30-50 \mathrm{~cm}$ long & $9-12 \mathrm{~cm}$ long \\
\hline Sepals & $\begin{array}{l}\text { white, after drying - blue or light } \\
\text { yellow, } 10-14 \mathrm{~mm} \text { long }\end{array}$ & light yellow, 7-8 mm long \\
\hline Spur & $\begin{array}{l}14-17 \mathrm{~mm} \text { long } \\
\text { blue with blue, rarely purple } \\
\text { longitudinal veins }\end{array}$ & 9-14 $\mathrm{mm}$ long \\
\hline Nectaries and staminodia & $\begin{array}{l}\text { yellow or yellow-orange, } 1-2 \mathrm{~mm} \\
\text { long }\end{array}$ & white, long: $1.5-2.5 \mathrm{~mm}$ long \\
\hline Hairs on the staminodia & $\begin{array}{l}15-19 \mathrm{~mm} \text { long, including stylodia } \\
4-6 \mathrm{~mm} \text { long }\end{array}$ & $\begin{array}{l}8-10 \mathrm{~mm} \text { long, including stylodia } \\
2-3 \mathrm{~mm} \text { long }\end{array}$ \\
\hline Follicles & & \\
\hline
\end{tabular}

Distribution. D. samurense is an endemic known only from southern Dagestan: Rutul district, the upper part of Samur River valley; the type of species range is South Dagestan. According to the botanical and geographical zoning of the Caucasus proposed by A. L. Takhtajan and Yu. L. Menitsky (Menitsky, 1991), this territory belongs to the Manas-Samur floral region situated in the southern part of Dagestan. It includes river basins of the Caspian Dagestan from Shura-Ozen River to Samur River. All locations of the species are situated in the upper part of the Samur River basin (fig. 7). The climate in the species habitat is continental with mild winters and summers. There are no accurate climatic data available for the habitat of the new species, but the average annual temperature in the nearby village of Luchek is known to be $+8{ }^{\circ} \mathrm{C}$, and the average annual rainfall in the nearby village of Mishlesh is 749 mm (Gadzhieva, Solovyev, 1996). Here steppemeadows on low-density gristly soils on the southern slopes and mixed small-leaved forests and subalpine meadows on brown soils on the northern slopes are commonly found (Chilikina, Schiffers, 1962).

Delphinium samurense grows in sparse shrub communities on a rocky-gravelly slope with a welldeveloped grass cover. Plant communities, where this species occurs, include such herbs as Phleum pratense L., Bromopsis variegata (M. Bieb.) Holub, Salvia verticillata L., Galium album Mill., Polygonum alpinum All., Campanula rapunculoides
L., Anthriscus nemorosa (M. Bieb.) Spreng., etc.; shrubs such as Rosa pimpinellifolia L., Berberis vulgaris L., Spiraea hypericifolia L., Cotoneaster sp.

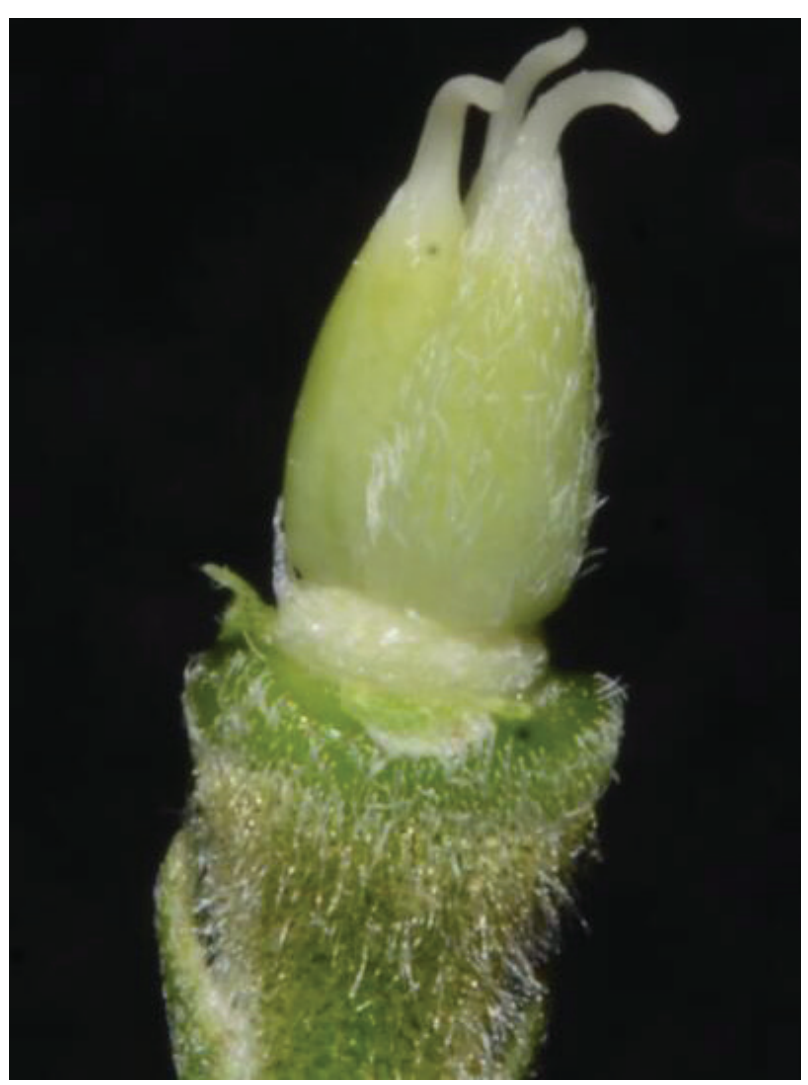

Fig. 4. The carpels of Delphinium samurense. 


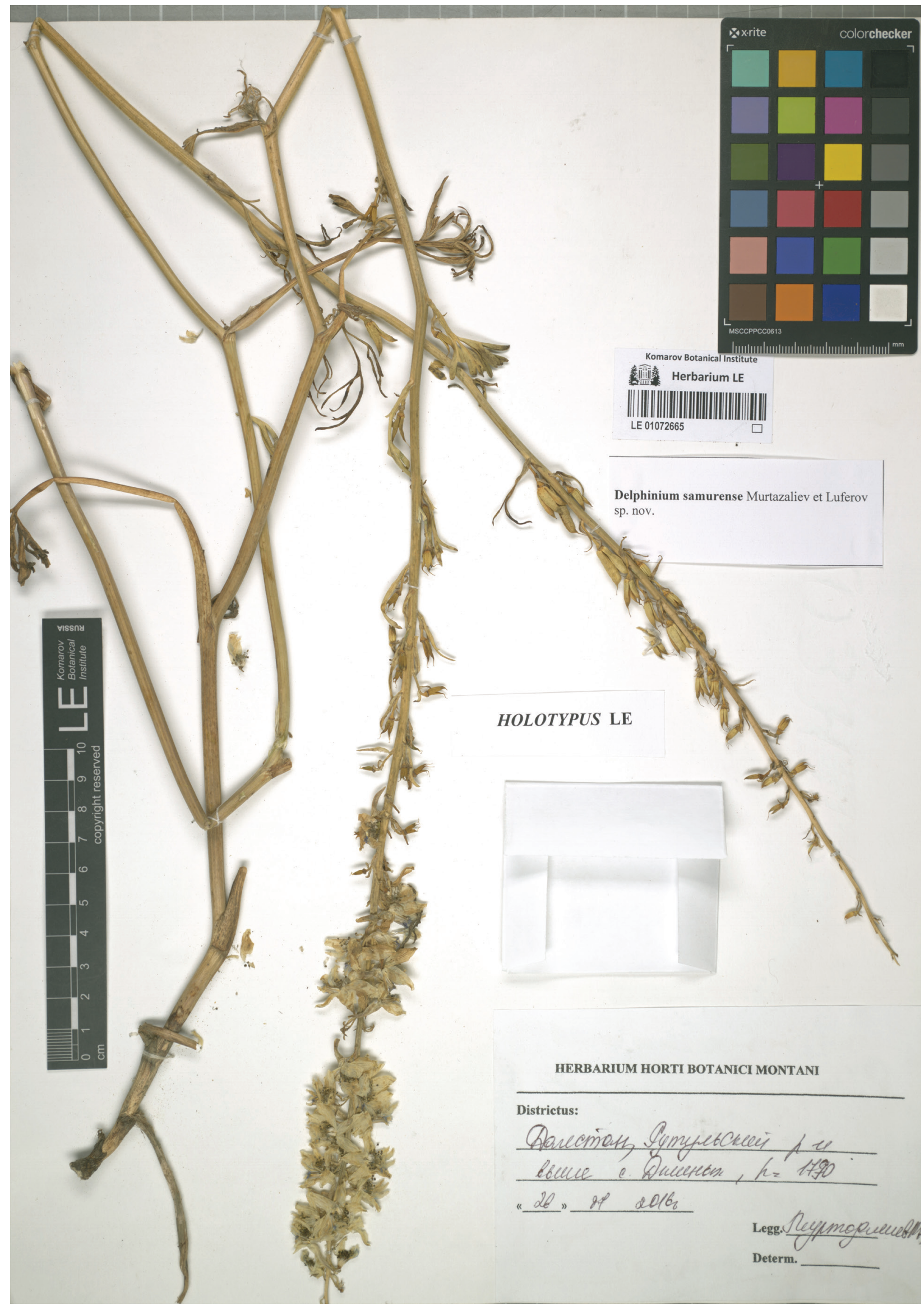

Fig. 5. The holotype of Delphinium samurense Murtazaliev et Luferov (LE). 


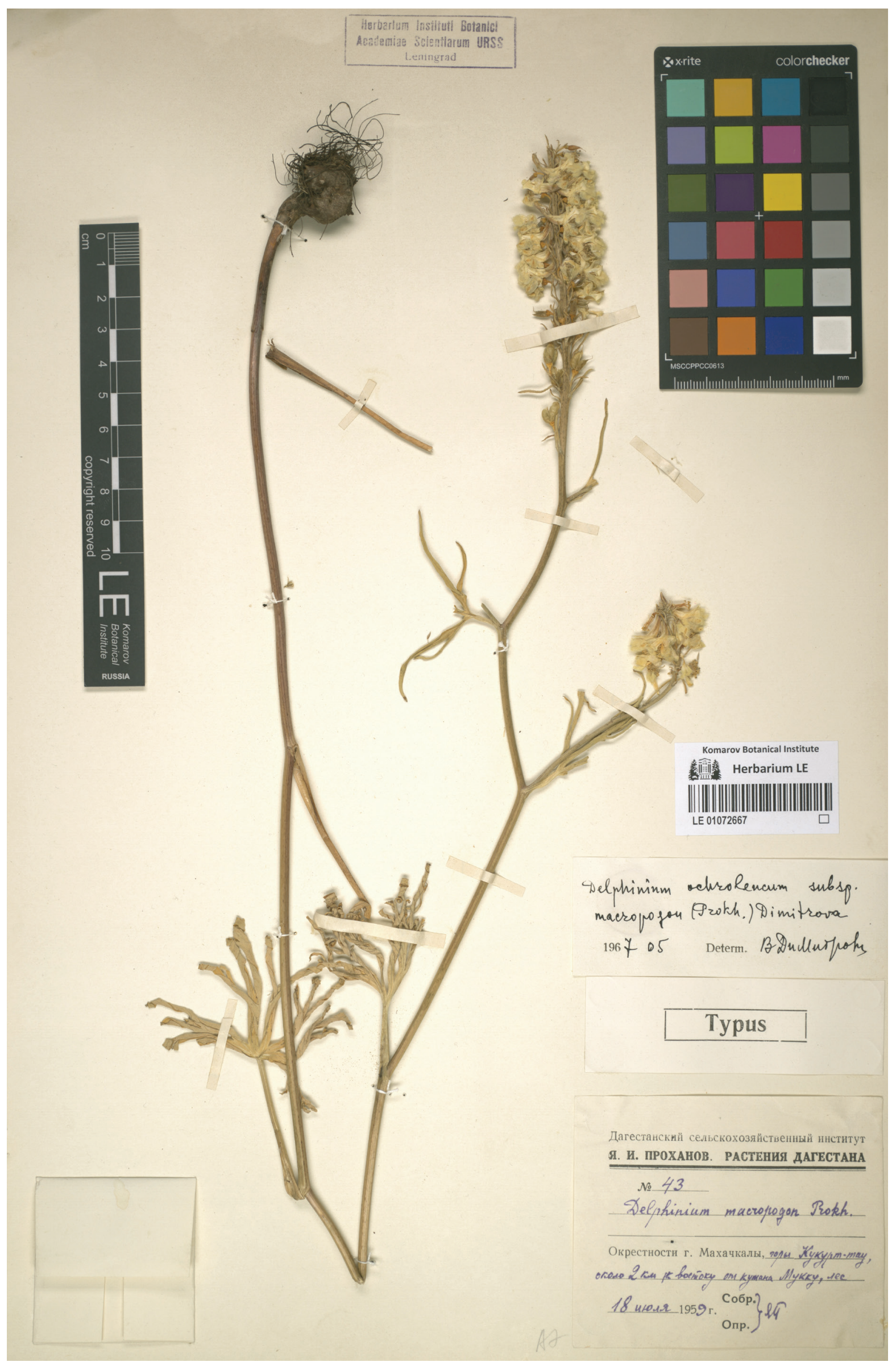

Fig. 6. The holotype of Delphinium macropogon Prokh. (LE). 


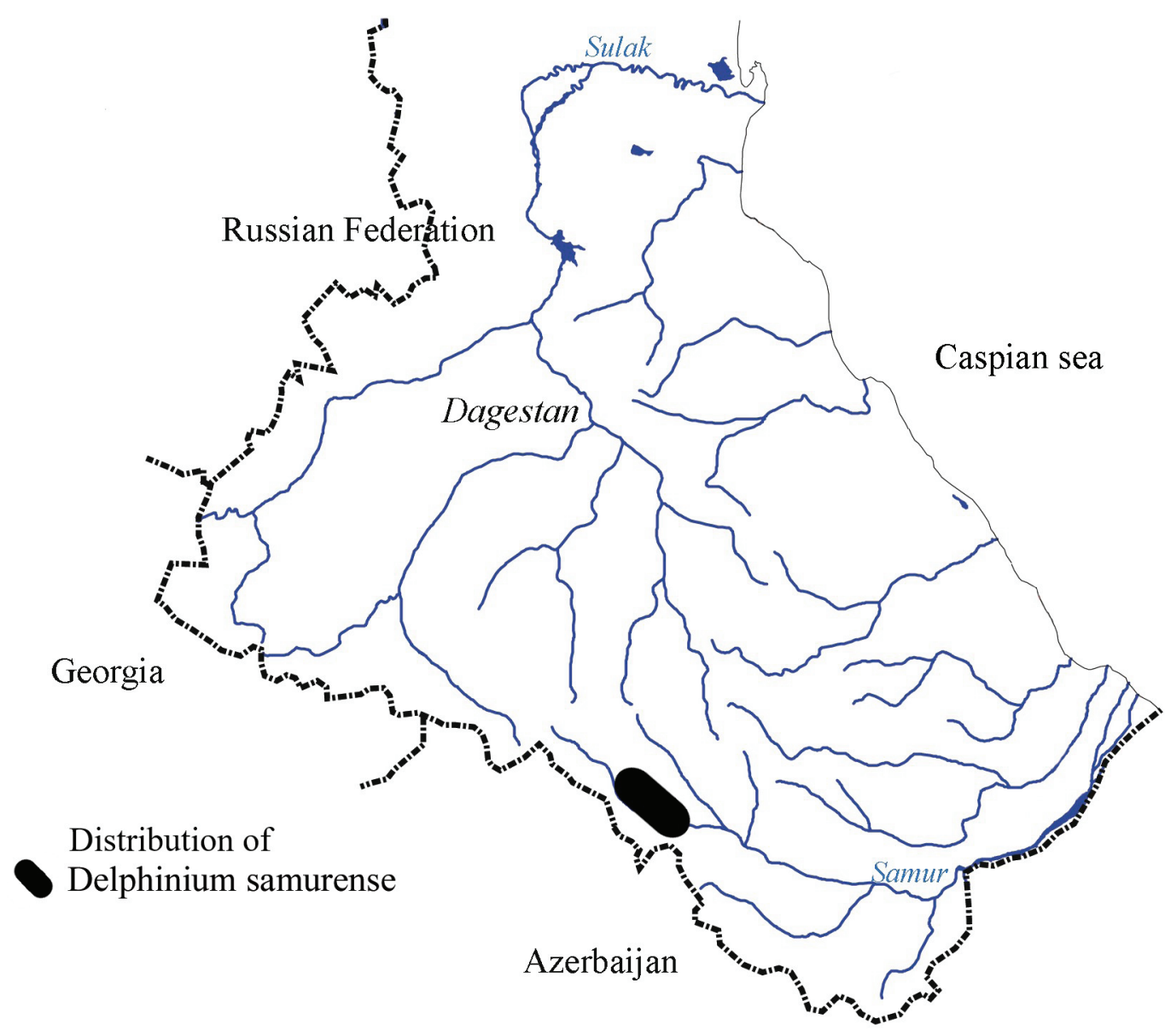

Fig. 7. The distribution map of Delphinium samurense.

A closely related species $D$. macropogon occurs in vicinities of Makhachkala: Talgi gorge, TarkiTau (Prokhanov, 1961; Murtazaliev, 2009, 2016; Anatov, 2020). The type of the species range is northern Dagestan.

The origin of $D$. samurense, in our opinion, is autochthonous, which was previously noted for the majority of other species of this genus in the flora of the Caucasus (Kemularia-Natadze, 1966; Kemularia-Natadze, Gagnidze, 1969; Gagnidze, 1974). For this territory, 40 species of Delphinium were listed (Luferov, 2012), of which 24 are endemic, that also indicates their indigenous origin.

Attention must be paid to conservation of D. samurense populations. They consist of 5-10 to 50 individuals, of which generative individuals predominate. Plants are scattered: dense thickets are not formed. Seed propagation is noticed, but during dry years the germination rate is low (up to $10 \%$ ), as well as plant survival, especially in the first 3 years of ontogenesis. The population range is small (not more than 20-70 $\mathrm{m}^{2}$ ).

The limiting factors are livestock grazing, haymaking, grass burning; potentially - collecting flowering plants for bouquets due to their high ornamental value. In addition, the safety of populations is of concern, given its proximity to the highway and settlements.

The narrowly endemic nature of $D$. samurense, the peculiarities of the population structure of natural communities (predominance of generative individuals and a very small number of plants in the virginal period of ontogenesis), low seed productivity and exposure to limiting environmental factors call for the need of making efforts to protect natural populations of the new species and include it in the new edition of the Red Data Book of the Republic of Dagestan. Possibility of introducing $D$. samurense into cultivation should also be estimated.

\section{Acknowledgements}

The authors are grateful to the V. V. Shvanova, junior researcher at the Komarov Botanical Institute of the Russian Academy of Sciences (BIN RAS), for help in the design of photographs of herbarium specimens. Supported by the Russian Academic Excellence Project 5-100 (Sechenov University). 


\section{REFERENCES / ЛИTEPATУРA}

Anatov D. M. 2020. Spatial Structure of the Population, Age Structure and Seed Production Delphinium macropogon Prokh. in the Talgi gorge. Biology Bulletin. 3: 274-282. [In Russian] (Анатов Д. М. Пространственная структура популяции, возрастной состав и семенная продуктивность Delphinium macropogon Prokh. в Талгинском ущелье // Изв. РАН. Сер. биол., 2020. № 3. C. 274-282). DOI: 10.31857/S0002332920010026

Chilikina L. N., Shiffers E. V. 1962. Karta rastitelnosti Dagestanskoy ASSR [Map of vegetation of the Dagestan ASSR]. Moscow; Leningrad: Publishing House of the USSR Academy of Sciences. 96 pp. [In Russian] (Чиликина Л. Н., Шифферс Е. В. Карта растительности Дагестанской АССР. М.; Л.: Изд-во АН СССР, 1962.96 с.).

Dimitrova V. N. 1969. Oligophyllon - a new subgenus of the genus Delphinium L. Novosti sistematiki vysshikh rasteniy [Novit. Sist. Pl. Vasc.] 6: 64-66. [In Russian] (Димитрова В. H. Oligophyllon - новый подрод рода Delphinium L. // Новости сист. высш. раст., 1969. Т. 6. С. 64-66).

Gadzhieva Z. Kh., Solovyev D. V. 1996. Chapter V. Climate. In: Akaev B. A., Ataev Z. V., Gadzhiev B. S. et al. Physical geography of Dagestan. Textbook. Moscow: Publishing House "School” Ltd. Pp. 150-184. [In Russian] (Гаджиева 3. Х., Соловьев Д. В. Глава V. Климат // Акаев Б. А., Атаев 3. В., Гаджиев Б. С. и др. Физическая география Дагестана. Учебное пособие. М.: Школа, 1996. С. 150-184).

Gagnidze R. I. 1974. Botaniko-geographicheskiy analiz florocenoticheskogo kompleksa subnivalnogo vysokotravya Kavkaza [Botanical and geographical analysis of the florocenotic complex of the subnival tallgrass of the Caucasus]. Tbilisi: Metsniyereba. 228 pp. [In Russian] (Гагнидзе Р. И. Ботанико-географический анализ флороценотического комплекса субнивального высокотравья Кавказа. Тбилиси: Мецниереба, 1974. 228 с.).

Grossheim A. A. 1950. Flora Kavkaza [Flora of Caucasus]. Vol. 4. Nymphaeaceae - Platanaceae. Moscow; Leningrad: Izdatelstvo Akademii nauk SSSR. 311 pp. + karte 356 + I-XXII pp. [In Russian] (Гроссгейм А. А. 1950. Флора Кавказа. Т. 4. Nymphaeaceae - Platanaceae. М.; Л.: Изд-во Академии наук СССР, 1950. 311 с. + карты 356 + I-XXII c.).

Huth E. 1895. Monographie der Gattung Delphinium. Botanische Jahrb. 20: 322-499.

Kemularia-Natadze L. M. 1966. Ranaliyevyye na Kavkaze i ikh taksonomiya [Ranunculaceae in the Caucasus and their taxonomy]. Tbilisi: Metsniyereba, 1966. 283 pp. [In Russian] (Кемулариа-Натадзе Л. М. Раналиевые на Кавказе и их таксономия. Тбилиси: Мецниереба, 1966. 283 с.).

Kemularia-Natadze L. M., Gagnidze R. I. 1969. Botanical and geographical review of Caucasian species of the genus Delphinium L. Notulae systematicae ac geographicae Instituti botanicae Thbilissiensis [Notes on plant systematics and geography]. Vasc. 27. Tbilisi: Metsniereba. Pp. 14-29. [In Russian] (Кемулариа-Натадзе Л. М., Гагнидзе $\boldsymbol{P}$. И. Ботанико-географический обзор кавказских видов рода Delphinium L. // Заметки по систематике и географии растений. Вып. 27. Тбилиси: Изд-во Мецниереба. 1969. С. 14-29).

Luferov A. N. 2012. Delphinium L. In: Konspekt flory Kavkaza [Caucasian flora Conspectus]. Vol. 3, Part 2. St. Petersburg; Moscow: KMK Scientific Press Ltd. Pp. 72-79. [In Russian] (Луферов A. Н. Delphinium L. // Конспект флоры Кавказа. Т. 3, часть 2. СПб.; М.: Тов-во науч. изд. КМК, 2012. С. 72-79).

Luferov A. N. 2018. The genus Delphinium L. In: Flora Nizhnego Povolzhya [Flora of the Lower Volga region]. T. 2: Dicotyledonous dicotyledonous flowering plants. Part 1. Salicaceae - Droseraceae. Moscow: KMK Scientific Press Ltd. Pp. 311-315. [In Russian] (Луферов A. Н. Род Delphinium L. - живокость // Флора Нижнего Поволжья. Т. 2, часть 1. Раздельнолепестные двудольные цветковые растения (Salicaceae - Droseraceae). М.: Тов-во науч. изд. КМК, 2018. С. 311-315).

Malyutin N. I. 1973. Phylogeny and systematics of the genus Delphinium L. Bot. Zhurn. 58(12): 1710-1722. [In Russian] (Малютин Н. И. Филогения и систематика рода Delphinium L. // Бот. журн., 1973. Т. 58, № 12. C. 1710-1722).

Malyutin N. I. 1987. The system of the genus Delphinium (Ranunculaceae) based on the morphological features of seeds. Bot. Zhurn. 58(12): 683-693. [In Russian] (Малютин Н. И. Система рода Delphinium (Ranunculaceae), основанная на морфологических признаках семян // Бот. журн., 1987. Т. 58, № 12. С. 683-693).

Malyutin N. I. 2001. The system of the genus Delphinium (Ranunculaceae). Bot. Zhurn. 86(8): 120-130. [In Russian] (Малютин Н. И. Система рода Delphinium (Ranunculaceae) // Бот. журн., 2001. Т. 86, № 8. С. 120-130).

Menitsky Yu. L. 1991. The project "The synopsis of the Caucasian flora". The Map of floristic districts. Bot. Zhurn. 76(11): 1513-1521. [In Russian] (Меницкий Ю. Л. Проект «Конспект флоры Кавказа». Карта районов флоры // Бот. журн., 1991. Т. 76, № 11. С. 1513-1521).

Munz P. A. 1967. A synopsis of the Asian species of Delphinium, sensu stricto. Journ. Arnold Arboretum 48: 476-545.

Murtazaliev R. A. 2009. Conspectus of the flora of Dagestan. Vol. 1 (Lycopodiaceae - Urticaceae). Makhachkala: «Epokha» Publ. House. 320 pp. [In Russian] (Муртазалиев Р. А. Конспект флоры Дагестана. Т. 1 (LycopodiaceaeUrticaceae) / Отв. ред. Р. В. Камелин. Махачкала: Изд. дом «Эпоха», 2009. 320 с.).

Murtazaliev R. A. 2016. The endemic flora of Dagestan and their distribution to floristic regions. Botanicheskiy vestnik Severnogo Kavkaza [Botanical Herald of the North Caucasus] 2: 33-42. [In Russian] (Муртазалиев P. A. 
Эндемики флоры Дагестана и их приуроченность к флористическим районам // Ботанический вестник Северного Кавказа, 2016. № 2. С. 33-42).

Nevsky S. A. 1937. The genus larkspur - Delphinium L. In: Flora SSSR [Flora of the USSR]. Vol. 7. Moscow; Leningrad: Izdatelstvo Akademii nauk SSSR. Pp. 99-183. [In Russian] (Невский С. А. Род живокость или шпорник - Delphinium L. // Флора CССР. Т. 7. М.; Л.: Изд-во Академии наук СССР, 1937. С. 99-183).

Pawlowski B. 1963. Dispositio systematica specierum europaearum generis Delphinium L. [Uklad systematyczny europejskich gatunkow rodzaju Delphinium L.]. Fragmenta floristica et geobotanica 9(4): 429-450. [In Latin, Annotation in Polish]

Prokhanov Ya. I. 1961. New species from North-Eastern Dagestan. Botanical materials of the Herbarium of the V. L. Komarov Botanical Institute of the USSR Academy of Sciences 21: 417-437. [In Russian] (Проханов Я. И. Новые виды из Северо-Восточного Дагестана // Ботанические материалы Гербария Ботанического института им. В. Л. Комарова Академии наук СССР, 1961. Т. 21. С. 417-437).

Tzvelev N. N. 1996. On some genera of the family Ranunculaceae in the Eastern Europe. Bot. Zhurn. 81(12): 112-122. [In Russian] (Цвелев Н. Н. О некоторых родах семейства лютиковых (Ranunculaceae) в Восточной Европе // Бот. журн., 1996. Т. 81, № 12. С. 112-122).

Tsvelev N. N. 2001. Genus larkspur - Delphinium L. In: Flora Vostochnoy Yevropy [Flora of Eastern Europe]. Vol. 10. St. Petersburg: Mir i semya; SPKHFA Publishing House. Pp. 66-74. [In Russian] (Цвелев Н. Н. 2001. Род живокость - Delphinium L. // Флора Восточной Европы. Т. 10. СПб.: Мир и семья; Изд-во СПХФА, 2001. С. 66-74).

Wang W. T., Warnock M. J. 2001. Delphinium Linnaeus. In: Flora of China. Vol. 6. Beijing: Science Press; St. Louis: Missouri Botanical Garden Press. Pp. 223-274. 